\title{
John R. Thelin \\ A History of American Higher Education
}

Second Edition. Baltimore:The Johns Hopkins University Press, 2011. 554 pp.

\section{Elea U. Herrera}

University of Texas

In this second edition, John R. Thelin once again gives us a comprehensive historical analysis of higher education in the United States. In the first edition, the historical timeline ends in the year 2000; in this edition the author has added the events and the debates of the first ten years of the twenty-first century that are pertinent to the study of higher education. By his own account, Thelin builds upon the work of other historians, in particular the work of Fredrick Rudolph and his seminal book, The American College and University: A History. He takes long held beliefs and challenges them, finding support for his arguments in long forgotten secondary sources. In doing so, Thelin provides his readers with a fresh perspective into the history of higher education in the United States while providing exciting vignettes that make reading more tangible.

Thelin begins his analysis in 1636, with the various colleges founded in colonial America and concludes in 2010 with the current state of institutions of higher education. Colonial times saw the founding of the colleges that we now call our "Ivy League" universities like Harvard, Yale, Princeton, Columbia and Brown. The charters of these institutions delineated their name, often honoring the crown or the colony in which they were found, as well as their chosen religion. Contrary to popular belief, these institutions were created as liberal arts colleges. They did offer theology classes but their main purpose was not to create clergy, they did not confer degrees in theology. In fact many of the young men that enrolled at these institutions used them as a forming ground to build their leadership skills, become "gentlemen scholars" but never actually graduated from the institution. This may have added to the belief that these institutions were only for an elite few, but this was not always the case, scholarships were available for individuals with low resources. The young men who were attending these institutions did so because their families could "do without" their help in the family business and therefore had the time to do so. 
The colonial colleges were primarily found in the northern colonies because the southern colonies were more agrarian and therefore families did not have as many virile young men to spare to attend college and often times the citizens of these colonies did not reflect the "dominant" religion that the institutions supported. This began to change after the revolutionary war. Suddenly there was an explosion of higher education institutions. Some historians refer to these institutions as "antebellum colleges" but Thelin argues that they are actually representative of a growth in nationalism (76). Previously established institutions dropped their colonial names and state colleges grew out of the new institutions. The curriculum taught also began to change with a growth of medical and law schools as well as normal schools. Courses in the sciences, engineering and agriculture also grew. Another innovative change was the establishment of higher education institutions for women.

Two major events in the 1860's brought about the next shift in higher education. The first was the Civil War and the second was the signing of the Morrill Land Grant in 1862. The Morill Act facilitated the western expansion of higher education institutions and the establishment of the land grant institutions that focused on agriculture and mining. The need for a "useful education" promoted the growth of scientific and technical education. As the curriculum continued to diversify so did the conversion from a college to a university. So that by the end of the nineteenth century and the start of the twentieth, a select group of institutions could call themselves a "real" university and through the establishment of the Association of American Universities attempted to define what a university should be. The consensus agreed that among other things it implied an increase in the number of graduating $\mathrm{PhDs}$, an increase in the number of professors with PhDs, and an increase in research and scholarly writings.

The twentieth century brought about a growth in the size of institutions of higher education as well as the diversity of the student body. By the end of World War II, universities in the U.S. were enjoying a "golden age" due largely to the G.I. Bill. Enrollment was so high, that public and private institutions were asked cooperate with each other and "share" the load. Additionally, in order to keep the United States competitive with other nations, universities were asked to increase the number of graduates with specialties in the maths and sciences. By the end of the century, the bubble had burst bringing about concerns about the dwindling external economic support.

Unlike some history books that tend to get mired in long verbose historical descriptions, Thelin's book is a pleasure to read. It brings to life the historical context in which higher education as an institution became the entity that we know today. He insures that in contextualizing a specific moment in time he provides a well-rounded account by including the role of women, students of color and other participants that in other accounts are often marginalized. Thelin also makes a concerted effort to describe the "student life" on the campuses he discusses and its importance to the growth of the institutions.

Some reviewers have criticized Thelin for putting too much emphasis on east coast schools specifically the Ivy Leagues. I disagree with this critique. On the contrary, the 
first chapters do have an emphasis on the institutions on the east coast, but as the number of higher education institutions grew in the United States to other parts of the country so does Thelin's inclusion of these institutions. Thelin even provides a comparison of schools in the United States with those in other countries within the Americas.

A History of American Higher Education is a "must read" for any scholar either teaching or taking a course in educational history. 